\title{
今月の症例 。
}

\section{インフルエンザを契機とした 副腎不全, 低Na血症の加療中に 横紋筋融解症を生じた1例}

高木 彩好，角谷美樹，森本 晶子，三好 晶雄，小阪 佳恵，角谷学，庄司 拓仁，小山 英則

59 歳, 男性. X-3 年にA病院で下垂体腺腫による下垂体前葉機能低下症と診断され, 補充療法中であった. X 年, B診療所でインフルエンザと診断され，2日後に意識障害，痙攣で当院に救急搬入された．血液検査で低 Na 血症を認め, 副腎不全の診断でステロイド補充とNa補正を開始した. 第2病日よりCK（creatine kinase）が上 昇し, 第4病日にCKが最高值となったが, 大量補液で腎機能の悪化なく軽快した. 低Na血症の補正による横紋 筋融解症の発症と考えられた.

〔日内会誌 109：1423～1431，2020〕

ポイント・低Na血症は稀ではあるが，横紋筋融解症の誘因となり得ることが知られている.

・浸透圧性脱髄症候群の予防のため, 10〜 $12 \mathrm{mEq} /$ 日以下にNa補正を行うべきと言われてい るが，横紋筋融解症の発症を防ぐためにもNa補正速度に注意が必要である.

Key words 横紋筋融解症，低Na血症，副腎不全

\section{はじめに}

横紋筋融解症は，骨格筋の破壊により細胞内成分 が血中に流入する病態であり, 原因として, 外傷, 痤 攣, 薬剂性, アルコール性, 感染, 筋疾患, 電解質 異常ならびに熱中症等が知られている11. 低Na血症に 伴う横紋筋融解症の症例報告も散見され, 急速な血 清Na補正が関連している可能性が指摘されている.

今回，インフルエンザを契機とした副腎不全 による低Na血症の加療中に著明なCK（creatine kinase）高值を伴う横紋筋融解症を生じた 1 例 を経験したので報告する。
症例

患者: 59歳, 男性.

主訴：意識障害, 瘥攣.

現病歴：X-3年に頭痛, 食思不振, 嘔気なら びに嘔吐を認めたため, A病院を受診した。血 液検査でNa $115 \mathrm{mEq} / \mathrm{l}$, ACTH $5.8 \mathrm{pg} / \mathrm{ml}$, cortisol $<0.6 \mu \mathrm{g} / \mathrm{dl}$, TSH $0.045 \mu \mathrm{IU} / \mathrm{ml}, \mathrm{FT}_{4} 0.86 \mathrm{ng} /$ $\mathrm{dl}$ を認め，基礎值から下垂体前葉機能低下症と 診断され，ヒドロコルチゾン $15 \mathrm{mg} /$ 日, レボチ ロキシンナトリウム $75 \mu \mathrm{g} /$ 日で補充療法を施行 されていた.頭部MRI (magnetic resonance imag- 
ing）で $3.8 \mathrm{~cm}$ 大の下垂体腺腫を認め, 視交叉圧 排ならびに両耳側半盲があり，手術を勧められ たが，単身赴任中で休みがとれない等の理由か ら，手術を希望されずサイズフォローとなって いた。

$\mathrm{X}$ 年, $38.5^{\circ} \mathrm{C}$ の発熱, 咳嗽が出現し, ヒドロ コルチゾンを $45 \mathrm{mg} /$ 日に増量して内服してい た。翌日より，嘔吐及び下痢が出現し，B診療 所にてインフルエンザA型と診断され，バロキ サビルを処方され, 解熱したが, その 2 日後に 意識障害及び痤攣が出現し, 当院に救急搬入さ れた。

既往歴：なし。

併存疾患：42歳より高血圧.

家族歴：なし。

嗜好歴: 喫煙20４0歳 $\times 20$ 本/日, 機会飲酒. 内服歴：ヒドロコルチゾン $15 \mathrm{mg}$, レボチロ キシンナトリウム $75 \mu \mathrm{g}$ ，バルサルタン $80 \mathrm{mg}$.

身体所見：GCS : E3V4M6. 身長 $174 \mathrm{~cm}$, 体 重73 kg. BMI (body mass index) $24.1 \mathrm{~kg} / \mathrm{m}^{2}$. 体温 $37^{\circ} \mathrm{C}$. 脈拍 71 /分, 整. 血圧 103/69 mmHg, $\mathrm{SpO}_{2}$ 98\% (RA).

心音は整で雑音は聴取せず, 呼吸音は清. 腹 部は平坦軟で肝脾を触知しない, 四肢浮腫な し. 腱反射六進減弱なし。

入院時血液検查所見 : 赤血球 420 万 $/ \mu 1, \mathrm{Hb}$ $12.2 \mathrm{~g} / \mathrm{dl}$, 白血球 $4,440 / \mu 1$, 血小板 15 万 $/ \mu 1$, 蛋白 $6.9 \mathrm{~g} / \mathrm{dl}, \quad A l b 4.3 \mathrm{~g} / \mathrm{dl}, \quad B U N 12 \mathrm{mg} / \mathrm{dl}, \mathrm{Cr}$ $0.53 \mathrm{mg} / \mathrm{dl}$, 尿酸 $4.6 \mathrm{mg} / \mathrm{dl}, \mathrm{eGFR} 121 \mathrm{ml} /$ 分/ $1.73 \mathrm{~m}^{2}$, TC $222 \mathrm{mg} / \mathrm{dl}$, TG $90 \mathrm{mg} / \mathrm{dl}$, HDL-C $48 \mathrm{mg} / \mathrm{dl}$, LDL-C $153 \mathrm{mg} / \mathrm{dl}$, 総ビリルビン $1.3 \mathrm{mg} / \mathrm{dl}$, AST $29 \mathrm{U} / 1$, ALT $19 \mathrm{U} / 1$, LD $192 \mathrm{U} /$ 1, $\gamma$-GTP 8 U/1, AMY 66 U/l, CK 426 U/1, CK-MB $7 \mathrm{U} / 1, \quad \mathrm{CRP} 1.64 \mathrm{mg} / \mathrm{dl}$, Na $113 \mathrm{mEq} / 1, \mathrm{~K}$ $3.5 \mathrm{mEq} / 1, \mathrm{Cl} 80 \mathrm{mEq} / 1$, 血漿浸透圧 $226 \mathrm{mOsm} /$ 1, FPG 95 mg/dl, HbA1c 5.6\%. TSH 0.033 mIU/ $\mathrm{ml}, \quad \mathrm{GH}<0.03 \mathrm{ng} / \mathrm{ml}, \quad \mathrm{LH}<0.3 \mathrm{mIU} / \mathrm{ml}, \quad \mathrm{FSH}$ $1.5 \mathrm{mIU} / \mathrm{ml}$, PRL $7.79 \mathrm{ng} / \mathrm{ml}$, ADH $1.9 \mathrm{pg} / \mathrm{ml}$, ACTH $<1.5 \mathrm{pg} / \mathrm{ml}$, cortisol $0.26 \mu \mathrm{g} / \mathrm{dl}$, DHEA-S
$<2 \mu \mathrm{g} / \mathrm{dl}, \quad \mathrm{FT}_{4} 1.19 \mathrm{ng} / \mathrm{dl}, \quad$ IGF-1 $55 \mathrm{ng} / \mathrm{ml}$ (-2.7SD), PAC $54.8 \mathrm{pg} / \mathrm{ml}$, PRA $0.7 \mathrm{ng} / \mathrm{ml} / 1$ 時間, 遊離テストステロン $<0.2 \mathrm{pg} / \mathrm{ml}$.

一ロXモ下垂体機能低下症で治療中，血液検査で 低Na血症を認め，感染を契機とした副腎 不全と判断した。

頭部CT (computed tomography)：下垂体腫瘍 を認める. その他, 頭蓋内に異常所見を認めず.

\section{臨床経過}

頭部CTでは, 下垂体腫瘍以外の異常所見を認 めず，低Na血症が意識障害及び痙攣の原因と考 えられた. 下垂体前葉機能低下症で補充療法中 であり, 発熱後はヒドロコルチゾンを増量して 内服されていたが，嘔吐，下痢で吸収されず， 副腎不全を発症したと考え, 点滴によるヒドロ コルチゾンの補充と Na補正を開始した。

受診時, Na 113 mEq/1でバルサルタンを中止 し， 11 時より $1.4 \% \mathrm{NaCl}$ の補液を開始したが, 6 時間経過後の 17 時にも Na $112 \mathrm{mEq} / 1$ と上昇を 認めなかった. Na濃度を $2 \% \mathrm{NaCl}$ に増量したと ころ, 第2 病日 7 時にNa $126 \mathrm{mEq} / \mathrm{ll}$ 上昇した. Naが上昇したため, $0.9 \% \mathrm{NaCl}$ に変更した。

第2病日血液検査：BUN $11 \mathrm{mg} / \mathrm{dl}, \mathrm{Cr} 0.71$ $\mathrm{mg} / \mathrm{dl}$, eGFR $88 \mathrm{ml} /$ 分 $/ 1.73 \mathrm{~m}^{2}$, AST $99 \mathrm{U} / 1$, ALT 26 U/1, LD 454 U/1, CK 18,012 U/1, CK-MB 14 U/1, Na 126 mEq/l, K 3.8 mEq/1, Cl 93 mEq/ 1, 浸透圧 $256 \mathrm{mOsm} / 1$, アルドラーゼ $29.6 \mathrm{U} / 1$. 尿検査：比重 $1.003, \mathrm{pH} 5.5$, 糖 $(-)$, 蛋白 $( \pm)$, 潜血 $(3+)$, 赤血球 $0 \sim 1 / \mathrm{HPF}$, 白血球 1 $\sim 4 / \mathrm{HPF}, \quad \mathrm{Na}<20 \mathrm{mEq} / 1, \mathrm{~K} 5.620 \mathrm{mEq} / 1, \mathrm{Cl}<$ $20 \mathrm{mEq} / 1$, Cr $23.1 \mathrm{mg} / \mathrm{dl}$, 浸透圧 $99 \mathrm{mOsm} / 1$.

一ロ玨筋原性酵素が上昇し，尿検査で潜血 $(3+) ，$ 尿中赤血球は認めず，ミオグロ ビン尿と考え, 横紋筋融解症と診断した。

意識状態は改善傾向であったが, CK 18,012 U/1と著明高值となり, 横紋筋融解症を 認めた. 


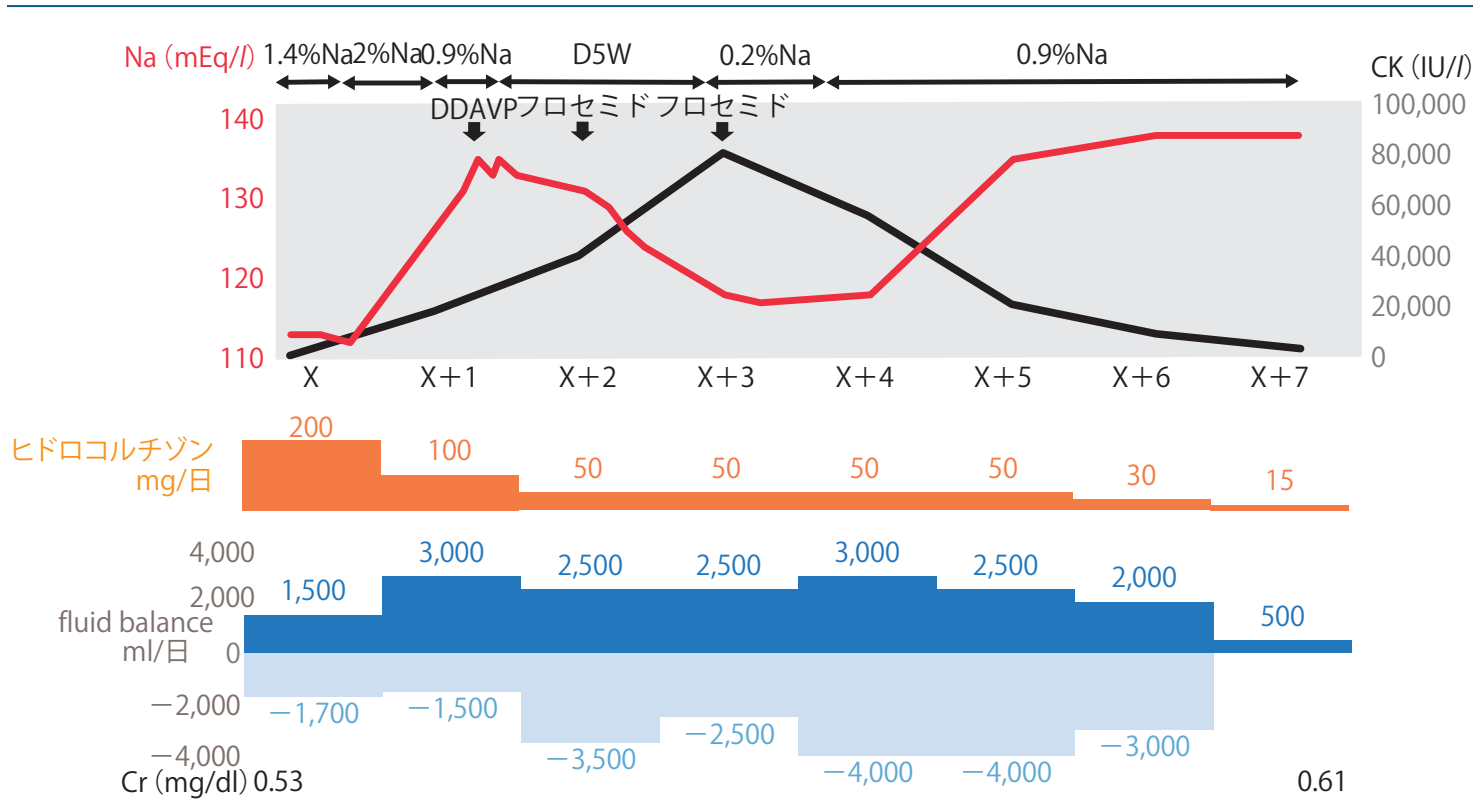

\section{図1 臨床経過}

$0.9 \% \mathrm{NaCl}$ に変更するも第 2 病日の 14 時半に Na $135 \mathrm{mEq} / 1$ まで上昇した. Na過剩補正のため DDAVP (1-desamino-8-D-arginine vasopressin) $12 \mu \mathrm{g}$ を投与し $5 \%$ ブドウ糖液に変更したとこ ろ, $\mathrm{Na}$ 上昇は止まり, 第 4 病日から維持液, 第 6 病日から生理食塩水に変更し, 以降, Naは緩 やかに改善した．急激な $\mathrm{Na}$ 変動を認めたが，入 院中の新たな神経症状の出現は認められず，浸 透圧性脱髄症候群は生じなかった。

CKについては，第2病日より上昇が持続し， 尿量がやや減少したため, 1 日2.5〜310補液を 行い，フロセミド $40 \mathrm{mg} 2$ 日間投与した. 第 4 病日にCK 80,546 U/1で最高值となったが, そ の後は改善し，第8病日で輸液を終了した。CK の著明な上昇を認めたが，腎機能は悪化なく経 過した（図1).

一ロXモ第 4 病日にCK 8 万U//と最高値となった が，1日2.5〜3/の補液で改善した。

全身状態改善後に下垂体腫瘍，下垂体機能低 下症に対し, MRIと下垂体機能評価を行った.

MRIでは, 囊胞変性を伴う $3.8 \times 2.8 \mathrm{~cm}$ 大の下
垂体腫瘍を認め, 3 年前と比較して腫瘍径の増 大は認められなかった。腫瘍の上方が囊胞状構 造で，下方は腫瘍実質成分を認女，囊胞部分が 上方へ進展し，視交叉の圧排を認めた（図2）. 意識障害改善後の身体所見で視野障害は認めら れなかったが，眼科視野検査では両耳側半盲， 同部位に一致する網膜神経線維層の菲薄化を認 めた。

一ロメモ 視野障害の自覚はなかったが，眼科視野 検査では両耳側半盲，同部位に一致する 網膜神経線維層の菲薄化を認めた。下垂 体腫瘍による視交叉圧排によると考え られた.

第 13 病日にインスリン負荷試験，第 14 病日 にACTH (adrenocorticotropic hormone)・コルチ ゾール日内変動と蓄尿検査, 第 15 病日に四者負 荷試験を施行した．MRIで視交叉に圧排する囊 胞変性を伴う巨大下垂体腫瘍を認め, TRH (thyrotropin releasing hormone）負荷試験では通常 の半量を投与し, 下垂体卒中の発症に注意して 施行した。 

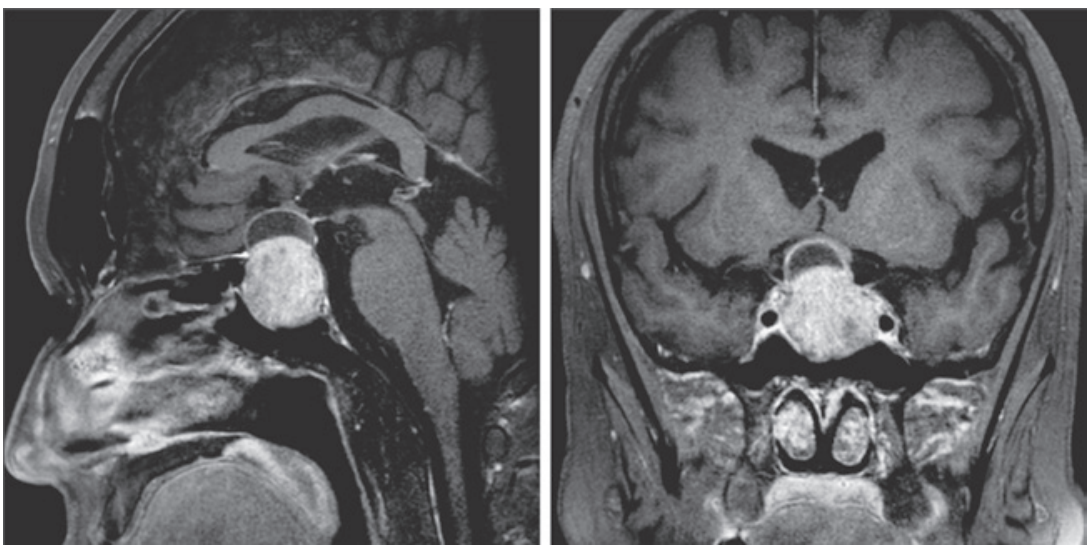

図2 下垂体MRI 造影T1強調画像

下垂体機能評価では, ACTH・コルチゾール日 内変動は消失, CRH (corticotropin-releasing hormone）負荷試験及びインスリン負荷試験で は, ACTH及びコルチゾール共に反応不良であっ た. TRH, LHRH (luteinizing hormone-releasing hormone) ならびにGHRH (growth hormone-releasing hormone）負荷試験ではPRL（prolactin） のみ反応良好で, その他の下垂体前葉機能低下 を認めた（図3）.

下垂体腺腫に対し，下垂体腫瘍摘出術を行う 予定となった。

\section{考察}

横紋筋融解症は，骨格筋の変性や壊死によ り, 細胞内成分が大量に血中あるいは尿中へ放 出され, 形成される病態であり, 明確な診断基 準が存在しておらず, 生化学検査, 自覚症状等 の所見から臨床的に診断する。本症例では，筋 症状は認められなかったが, 筋原性酵素とアル ドラーゼ值が上昇し，ミオグロビン尿を認め, 横紋筋融解症と診断した。

原西らによる非外傷性横紋筋融解症 298 症例 の文献的検討では, 原因として薬剤性が最も多 く, 次いで, 感染症, 高血糖性昏睡, 水中毒,
アルコール中毒の順に認められた. 水中毒で は, 痙攣，低Na血症ならびに低浸透圧血症が横 紋筋融解症の発症に関与するとされている11).

本症例は, 発熱時にヒドロコルチゾンを増量 して内服していたが, 嘔吐, 下痢のため吸収困 難となり，副腎不全を来たし，低Na血症，低血 漿浸透圧血症に至ったと考えられる，意識障 害, 痙攣は低Na血症が原因と考えられ, $\mathrm{Na}$ 補正 後は認められなかった。

また，入院時に低レニン低アルドステロン血 症を来たしADHの不適切な上昇を認め, 副腎不 全に伴う水利尿不全により, 有効循環血液量が やや増大していた可能性とバルサルタンによる アルドステロン抑制が考えられた。

横紋筋融解症によるCK上昇は, 横紋筋融解症 発症から 12 時間以内に上昇を始め，24時間前 後でピークに達すると言われているが2), 本症 例では，第 4 病日にCKの最高值を認めた。 入院 前に診断されていたインフルエンザの存在だけ でなく, 低Na血症, Na補正が横紋筋融解症に大 きく寄与したと推測された.

一ロXモ 低Na血症は稀ではあるが，横紋筋融解症 の誘因となり得ることが知られている。

低Na血症による横紋筋融解症の発症機序と して, 主に2つの説が提唱されている.1つは, 


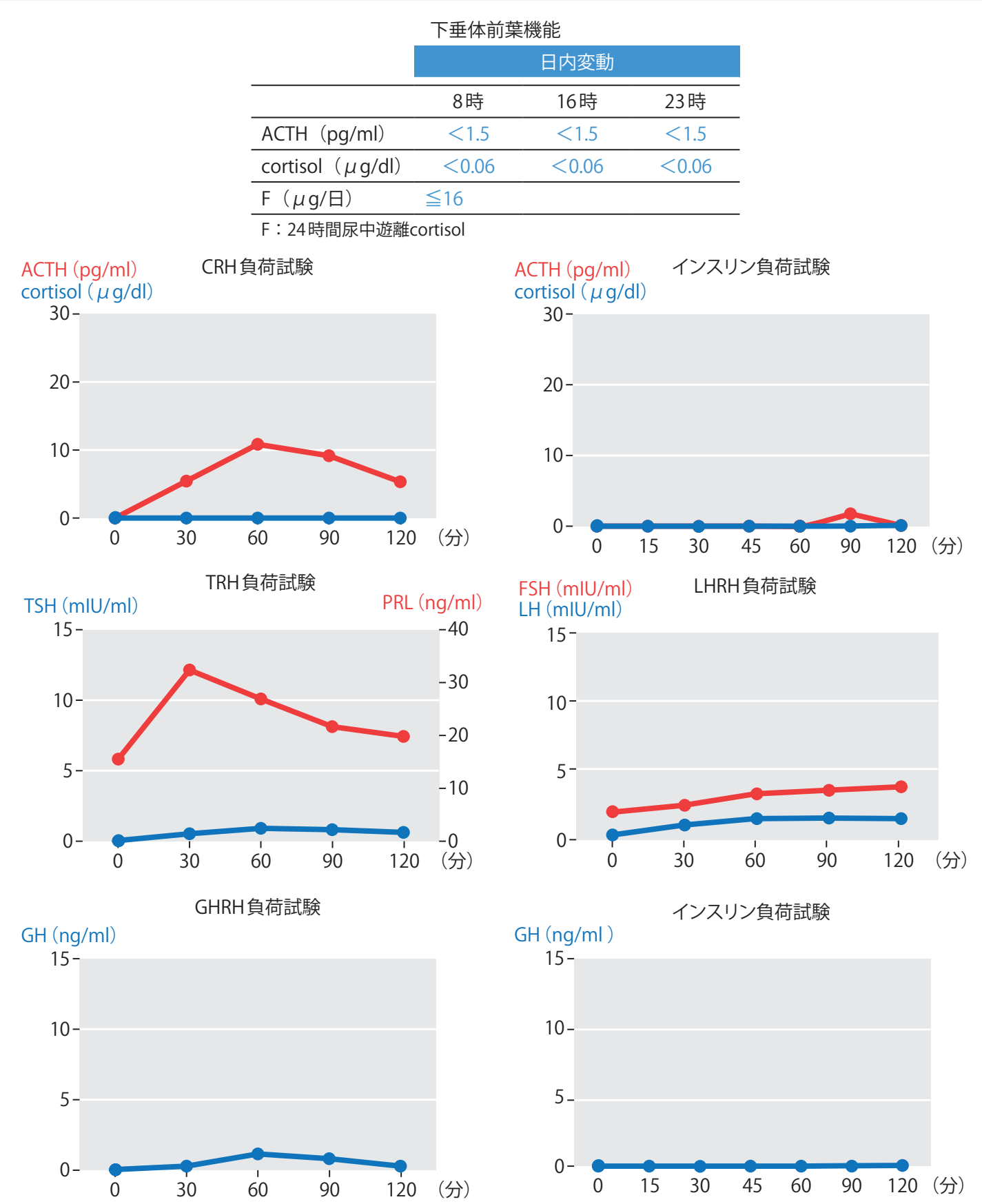

図3下垂体機能評価の結果

細胞外 $\mathrm{Na}$ 濃度の低下により，横紋筋の細胞膜上 のNa-Ca交換系の機能が低下する。そのため, 細 胞内Caイオン濃度が上昇し, Ca依存性プロテ アーゼ等の酵素が活性化され, 細胞障害が起こ
るという説である ${ }^{3)}$ 。もう 1 つは, 細胞外浸透圧 の低下により, 細胞が膨張, 細胞膜が脆弱化し, 細胞内の酵素が逸脱するという説である ${ }^{4)}$. 後 者では, 浸透圧の急激な補正も同様の変化を引 


\begin{tabular}{|c|c|c|c|}
\hline & \multicolumn{2}{|c|}{ 横紋筋融解症 } & \multirow{2}{*}{ p值 } \\
\hline & $(+)$ & $(-)$ & \\
\hline 入院時Na（mEq/l) & 110 & 110 & 0.13 \\
\hline $\begin{array}{l}\mathrm{Na} \text { 補正開始後 } 12 \text { 時間の } \\
\text { 補正速度 (mEq///1 時間) }\end{array}$ & 1.22 & 0.71 & $<0.001$ \\
\hline $\begin{array}{l}\mathrm{Na} \text { 補正開始後24時間の } \\
\text { 補正速度 }(\mathrm{mEq} / / / 1 \text { 時間) }\end{array}$ & 1.11 & 0.60 & $<0.001$ \\
\hline $\begin{array}{l}\text { 補正開始後48時間の補正 } \\
\text { 速度 (mEq/l/1 時間) }\end{array}$ & 0.58 & 0.57 & 0.19 \\
\hline
\end{tabular}

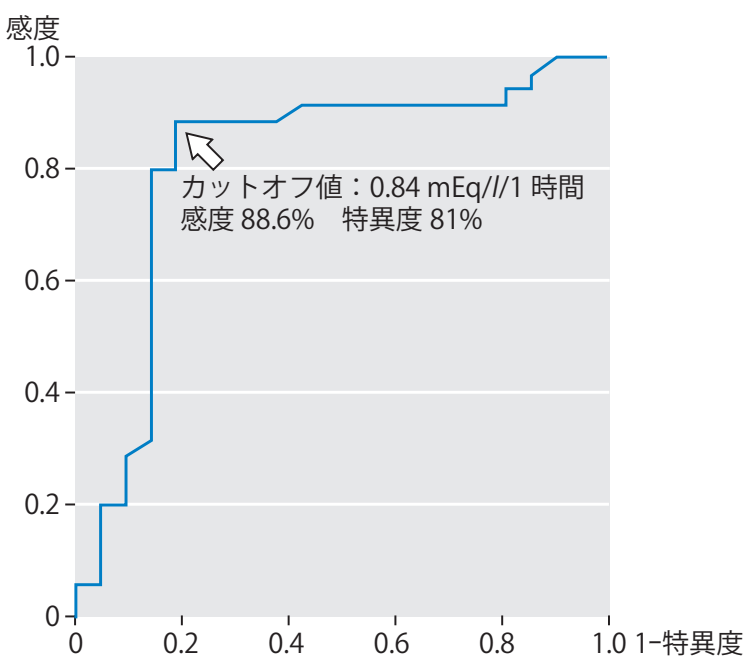

図4 Na補正速度と横紋筋融解症の関連（文献5より改变引用）

き起こすとしている，以上より，横紋筋融解症 の発症には, 低Na血症, 低血漿浸透圧血症なら びに血漿浸透圧值の補正速度が関与していると 考えられる.

横紋筋融解症を来たした低Na血症の既報の 多くは水中毒によるものであり, 柏浦らの水中 毒によるNa補正を行った 56 症例の報告では, 横 紋筋融解症発症群で発症しなかった群と比較 し, 補正後 12 時間, 24 時間以内での補正速度が 優位に速かった。血清Naの補正速度に関する ROC (receiver operating characteristic) 曲線で は, $0.84 \mathrm{mEq} / 1$ をカットオフ值にすると横紋筋 融解症の発症において, 感度88.6\%, 特異度 $81 \%$ と示されており ${ }^{5}$ (図 4), 本症例では, 第 1 病日 17 時Na $112 \mathrm{mEq} / 1$ から上昇し, 第2病日 14 時 30 分にNa $135 \mathrm{mEq} / 1$ となった. $\mathrm{Na}$ 変動は $1.07 \mathrm{mEq} / 1 / 1$ 時間であり, 補正速度が横紋筋融 解症発症に関与したと考えられた. Na補正は浸 透圧性脱䯣症候群の予防のため, 10〜 $12 \mathrm{mEq} /$ 日以下が望ましいとされており ${ }^{6)}$, 過剩補正の際 は $5 \%$ ブドウ糖液, デスモプレシン投与で一旦
Na濃度を低下させることが有用とされてい る7)．横紋筋融解症の発症を防ぐためには, 24 時間以内の Na補正速度にも注意が必要と考える.

\section{最終診断}

\section{>インフルエンザを契機とした}

\section{副腎不全, 低Na血症のNa補正による 横紋筋融解症}

\section{おわりに}

今回, 副腎不全による低Na血症, Na補正が影 響したと考えられる横紋筋融解症を生じた 1 例 を経験した。低Na血症の補正には頻回な血液検 査を行い, 補正速度の調整を慎重に行い, 浸透 圧性脱髄症候群や横紋筋融解症の発症を防ぐ必 要がある.

著者のCOI (conflicts of interest) 開示: 本論文発表内容 に関連して特に申告なし 
1）原西保典, 他：本邦における非外傷性横紋筋融解症例の文献的検討. ICUとCCU 28 : 929-933, 2004.

2) Ram P : Rhabdomyolysis. John M, eds. Rosen's Emergency Medicine - Concepts and Clinical Practice. 8th eds, Saunders, Philadelphia, 2014, 1667-1675.

3) Singhal PC, et al : Rhabdomyolysis in the hyperosmolal state. Am J Med 88 : 9-12, 1990.

4) Rizzieri DA : Rhabdomyolysis after correction of hyponatremia due to psychogenic polydipsia. Mayo Clin Proc $70: 473-476,1995$.

5) Kashiura $\mathrm{M}$, et al : Association between rapid serum sodium correction and rhabdomyolysis in water intoxication : a retrospective cohort study. J Intensive Care 5 : 37, 2017.

6) Sterns RH : Disorders of plasma sodium--causes, consequences, and correction. N Engl J Med 372:55-65, 2015.

7) Sood L, et al : Hypertonic saline and desmopressin : a simple strategy for safe correction of severe hyponatremia. Am J Kidney Dis 61 : 571-578, 2013. 
今月の症例 。

症例掲載施設紹介

\section{兵庫医科大学 内科学 糖尿病内分泌 - 免疫内科}

（糖尿病 $\cdot$ 内分泌 $\cdot$ 代謝内科）

身近な生活習慣病から遺伝病や高度な専門性 を必要とする疾患の診療まで幅広く対応し, 糖 尿病グループ, 内分泌・代謝グループがそれぞ れ地域の中核施設として阪神地区の医療体制を 支えています。また, 臨床・基礎研究面でも各 グループで日々切硣琢磨し, また連携しながら, 新たな情報を世界に向け発信し続けています。

\section{【各グループの診療・研究の特色】}

\section{口糖尿病グループ}

日本糖尿病学会認定教育施設として, 2019年 12月末現在, 4 名の日本糖尿病学会認定指導医, 12名の専門医を有し, 持続皮下インスリン注入 (continuous subcutaneous insulin infusion : CSII）療法及びSAP（sensor augmented pump） 療法等の先進糖尿病医療と, 糖尿病合併症の予 防及び管理を 2 本柱とした診療に注力していま す. 年間約 350 名の糖尿病患者の入院患者を主 科として，また，周術期等約 1,000名以上の共 観患者の対応にあたっています.
先進糖尿病医療の開発, 夜間低血糖 - 糖尿病 性血管合併症を標的にしたコホート研究，個別 糖尿病薬の臨床的評価等を中心とした臨床試験 と, 膵 $\beta$ 細胞 $-\alpha$ 細胞機能障害と糖尿病合併症 メタボリックメモリーを標的とした基礎研究を 行っています。

\section{口内分泌・代謝グループ}

日本内分泌学会認定教育施設として, 2019年 12 月末現在, 5名の内分泌代謝科指導医 - 専門 医を有し, また, 内分泌・代謝グループは, 症 例数で間脳・下垂体, 副腎疾患がDPC (diagnosis procedure combination）10位以内をキープする 等, 年間約 350 例の入院診療を経験可能な内分 泌疾患の中核施設です。外科部門とも密接に連 携しており，手術前後の経過を長期に亘って当 科がフォローする体制を確立しています。家族 性高コレステロール血症の専門診療施設として 日本動脈硬化学会から認定されている等, 日本 動脈硬化学会認定専門医・指導医も有していま

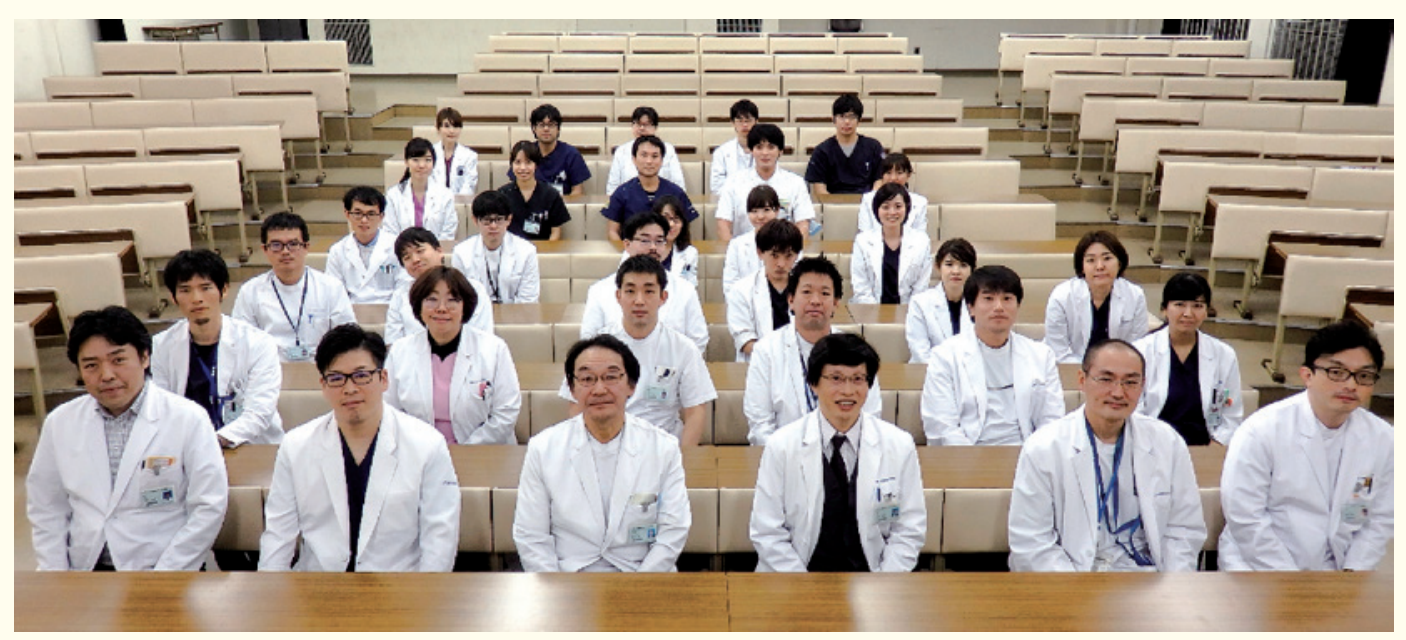

当科は日本内科学会，日本糖尿病学会，日本内分泌学会，日本動脈硬化学会の認定施設です. 
す. 2018年からは, 上部消化管外科をはじめと した多数の科と協力し, 高度肥満症に対する手 術加療にも取り組んでいます。

主に肥満, メタボリックシンドローム, イン スリン抵抗性の病因・病態の解明, 副腎皮質ホ ルモン合成制御機構の解明ならびにプリン・ピ リミジン代謝の病態と制御を目的とした基礎研 究と, 疲労・睡眠・自律神経機能障害等ストレ 又応答の内分泌・代謝疾患における意義を解明 することを目的とした前向きコホート研究を中 心に, 研究を行っています.
副腎疾患, 甲状腺クリーゼに関する多施設共 同研究にも参加しています.

\section{ホームページ}

https://www.hyo-med.ac.jp/department/diab/ index.html

文責 : 兵庫医科大学内科学

糖尿病内分泌・免疫内科

助教 角谷 美樹 